\title{
蓲床 大動脈炎症候群に発症した多発性筋炎に伴う
}

\author{
びをん性間質性肺炎の 1 例
}

\author{
東京都立墨東病院内科 \\ 横山 芳正。 廣瀬 英生
}

\section{A CASE OF AORTIC ARCH SYNDROME, ASSOCIATED WITH POLYMYOSITIS AND REVERSIBLE INTERSTITIAL PULMONARY DISEASE}

Yoshimasa Yokoyama, MD and Hideo HiRose, MD

Department of Internal Medicine, Bokuto General Hospital, Tokyo

\begin{abstract}
概要 33 才時左橈骨動脈触知不能を指摘された女性が，8年後筋力低下，呼吸困難を呈し，臨 床病理学的娭索により大動脈炎症候群，多発性筋炎，びんま性間質性肺炎の合併が明らかとな つた。本例の上5に，大動脈炎症候群，多発性筋炎，びすん性間質性肺炎の 3 疾患を合併した 症例はこれまで報告がない.本症例の肺発症の成因として自己免疫的機序の関与が示唆された。 3 疾患の合併は共通の免疫異常に基つく病態と推察されるので, 本症例は自己免疫疾患にお゙け る多彩な病態の発現に関し重要な症例と考号られる。
\end{abstract}

はじめに

多発性筋炎に伴うびまん性間質性肺炎は，近年

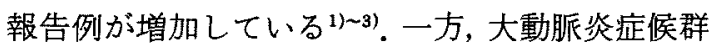
に伴う膠原病流について最近注目を集めている が，大動脈炎症候群，多発性筋炎，びまん性間質 性肺炎の 3 疾患を合併した症例はこれまで報告が ない。

われわれは，大動脈炎症候群に発症した多発性 筋炎に伴うびまん性間質性肺炎の1例を経験し た．免疫学的に興味ある症例と考えられるので， ここに報告する。

患者：41才，家婦。

主訴：息切れ，下肢の筋力低下。

家族歴：特記すべきことなし。

既往歴：1967年肺結核を発見され，1971年よ り1976年 2 月まで断続的に治療した。

現病歴：1968年（33才）第3子出産時左橈骨 動脈触知不能といわれた。1976年 3 月中旬顔面,

[昭和56年 9 月 12 受稿]
手・足に浮属を生じ 4 月23日当科初診。受診時浮 腫はみられず尿蛋白陰性であつたが，血沈促進( 1 時間値 $57 \mathrm{~mm}), \mathrm{GOT}$ 上昇(105U), RAテスト(H), Waaler-Rose反応256倍を示した. 5 月12日顔面に 浮睡を生じ受㟝し，血清酵素活性值の上䒜 (GOT153, LDH375)がみられた。 6 月上旬労作時 息切れ，6月末レイノ一症状が出現した。7 月中 旬上り息切れが増強し，トイレで立ら上るのが困 難となり下肢の筋力低下を来し 7 月 30 日当科入 院.

入院時現症：体格中等大, 体温 $36.4^{\circ} \mathrm{C}$, 脈拍 120 整，左橈骨動脈触知せず。血王右上腕 $90 / 70$ $\mathrm{mmHg}$, 左上腕測定不能. 心音胸骨左縁第 3,4 肋間で拡張期吹鳴性雑音 (L2/6度) 聴取。呼吸音 清, ラ音はない。腹部平坦軟, 肝・脾触知せず。 リンパ節腫脹なし，近位筋の萎縮を認め，握力は 右 $3.5 \mathrm{~kg}$, 左 $4.5 \mathrm{~kg}$. 下肢の腱反射軽度元進. 病的 反射 $(-)$.

臨床検查成績（表 1)：1）尿・䔬便；異常 ない，2）末梢血； 経過中赤血球数 $258 \times 10^{4}$ $-434 \times 10^{4} / \mathrm{mm}^{3}$, 血色素量 $7.5 \sim 12.5 \mathrm{~g} / \mathrm{dl}$, 白血球 
表 1 . 入院時検查成綪

\begin{tabular}{|c|c|c|c|c|}
\hline 末梢血 & & 生化学 & & 免没血清娭查 \\
\hline 赤血球数 & $408 \times 10^{4}$ & 総蛋白㻎 & $7.9 \mathrm{~g} / \mathrm{dl}$ & RA テスト \\
\hline 血色续壆 & $11.8 \mathrm{~g} / \mathrm{dl}$ & Alb & $57.2 \%$ & Waaler-Rose \\
\hline $\mathrm{Ht}$ & $36.6 \%$ & $\alpha_{1-g l}$ & $4.8 \%$ & $\mathrm{CRP}$ \\
\hline 網赤血阷 & $11 \% 0$ & $\alpha_{2} \cdot \mathrm{gl}$ & $14.8 \%$ & 100Todd \\
\hline 血小板数 & $29.6 \times 10^{4}$ & $\beta$-gl & $3.1 \%$ & 抗核抗体 \\
\hline 白血球数 & 6,900 & $r \cdot \mathrm{gl}$ & $20.1 \%$ & LE 細胞 \\
\hline 桿核球 & $19 \%$ & BUN & 10 & 寒椧凝集反応 \\
\hline 分節核球 & $48 \%$ & クレアチ =ン & 0.8 & 梅静血请反底 \\
\hline 好酸球 & $5 \%$ & $\mathrm{Na}$ & 137 & PPD \\
\hline リンバ球 & $27 \%$ & K & 4.5 & ウイルス抗体 \\
\hline 単球 & $1 \%$ & $\mathrm{Cl}$ & 100 & $2,500 \mathrm{mg} / \mathrm{dl}$ \\
\hline 血沈 1 時間値 & $129 \mathrm{~mm}$ & 総コレステロ & $-2 \quad 216$ & $246 \mathrm{mg} / \mathrm{dl}$ \\
\hline 康 & & alk-P-ase & $96 \mathrm{mU} / \mathrm{ml}$ & $204 \mathrm{mg} / \mathrm{dl}$ \\
\hline 蛋白 & $(-)$ & GOT & 302 & $545 \mathrm{U} / \mathrm{ml}$ \\
\hline 糖 & $(-)$ & GPT & 126 & T cell : E-rosette $76 \%$ \\
\hline 沈潜 & 正常 & $\mathrm{CPK}$ & 162 & B cell : EAC-rosette $25.4 \%$ \\
\hline 粸便 & & aldolase & 37.5 & Fc-rosette $16.7 \%$ \\
\hline 潜血 & $(-)$ & LDH & 651 & \\
\hline 虫臯 & $(-)$ & 属クレフォン & $31.3 \mathrm{mg} / \mathrm{dl}$ & \\
\hline
\end{tabular}

数6500 20600/ $\mathrm{mm}^{3}$. 3) 血沈：入院時 1 時間 值 $129 \mathrm{~mm}$ と高度促進を示し, 胸水括よび心膜炎発 現時にも著明な促進を示した.4）生化学；血清 総蛋白量 $5.1 \sim 7.9 \mathrm{~g} / \mathrm{dl}, \gamma-\mathrm{gl} 1.5 \sim 2.7 \mathrm{~g} / \mathrm{dl}$ と増 加した. 血清酵素活性值は初診時よりGOTの上昇 がみられ，8月上旬GOT 375, GPT $145, \mathrm{LDH}$ 735, CPK 162, aldolase 37.5 と最高值を示したが, 以後低下し11月上旬正常值に復した.5）免疫血清 反応： RAテスト (H), Waaler-Rose反応は 4 月256倍， 7 月 1024 倍， 8 月64倍，9月以降陰性之 なつた，梅毒血清反応，抗核抗体，LE細胞，PPD はすべて陰性．血清ウイルス抗体はインフルエン ザ,ムンプス，アデノウイルス，ヘルペス，サイ トメガロ，コクサッキー，エコーはすべて陰性. 抗ミトコンドリア抗体, 抗平滑筋抗体, 抗マイク ロゾーム抗体，抗甲状腺抗体もすべて陰性。immune complex $\left(\mathrm{C}_{1} \mathrm{q}\right.$ solid-phase EIA法) は1.7 $\mu \mathrm{g} / \mathrm{ml}$ (対照 $3.0 \mu \mathrm{g} / \mathrm{ml}$ 以下) と正常值を示した。

6) HLA抗原：HLA typingではA2, A26 (10), B7, B15, CW3抗原の存在を認めた。 7) 免疫グ口 ブッン； IgG $2500 \mathrm{mg} / \mathrm{dl}, \mathrm{IgA} 246 \mathrm{mg} / \mathrm{dl}, \operatorname{IgM}$ $204 \mathrm{mg} / \mathrm{dl} . \mathrm{IgE} 545 \mathrm{U} / \mathrm{ml}$ (正常人平均値 $122 \mathrm{U} / \mathrm{ml}$ ) と高值を示した，8）PSP15分26\%，120分77\%.
9）皮内反応：抗原液は市販のアレルゲンェキ スを使用し，判定は発赤20－39mmを陽性とした。 ハウスダストは弱陽性 $(21 \times 21 \mathrm{~mm})$ であつたが， アカマッ, ブタクサ，スギ，綿，ソバガラに対す る即時反応情すべて陰性, カンジダ( 1 万倍, 0.02 $\mathrm{ml})$, ペニシリウム, アルテルナリア, アスペルギ ルスに対する即時型および遅延型反応はすべて陰 性であつた，10）肺機能 (表 2)； 入院時 (1976 年 8 月 6 日)\%肺活量打よび 1 秒率はそれぞれ $65.6 \%$ 扩よび77.5\%と低下し，肺コンプライアン スは0.055と著明な低下を示した. 10 月 4 日\%肺活 量は 47.5 とさらに低下し高度の拘束性障害を示し た。 $\mathrm{D}_{\mathrm{LCO}}$ は入院時 12.7 と低下を示し，10月 4 日 20.2となつたが，その後次第に低下し拡散障害が 増強した。 $\mathrm{Po}_{2}$ は入院時68.7と低下を示した。

血管造影； 大動脈撮影で矢印に示すごとく左 鎖骨下動脈の閉塞を認める（図 1 ）。

胸部X線写真：入院時 (1976年8月 5 日)右肺 外側寄り括よび両側下肺野にスりガラス様陰影を 認めた(図 2 )。次第に右肺の陰影が払大し，心陰 影も拡大した(図 3 )。胸水貯留と心膜炎による心 陰影の著明な拉大(図4)を認めたが, 肺発症の 4 力 月後異常所見はほとんど消失した，肺シンチグラ 
表 2 , 肺機能検査

\begin{tabular}{|c|c|c|c|c|c|}
\hline & & $\begin{array}{c}1976 \\
8 \text { 月 } 6 \text { 日 } \\
\end{array}$ & 10月 4 日 & 12月20日 & $\begin{array}{c}1977 \\
1 \text { 月14日 } \\
\end{array}$ \\
\hline 肺活量 & \multirow[t]{2}{*}{$l$} & 1.8 & 1.3 & 1.8 & 2.0 \\
\hline$\%$ 肺活星 & & 65.6 & 47.5 & 64.6 & 74.2 \\
\hline 1 秒量 & $l$ & 1.4 & 1.2 & 1.5 & 1.6 \\
\hline 1 秒率 & $\%$ & 77.5 & 92.7 & 84.1 & 76.5 \\
\hline \multicolumn{2}{|c|}{ DLco $\mathrm{ml} / \mathrm{min} / \mathrm{mmHg}$} & 12.7 & 20.2 & 17.0 & 14.4 \\
\hline \multicolumn{2}{|c|}{$\%$ DLco } & 50.7 & 82.4 & 70.4 & 55.2 \\
\hline \multicolumn{2}{|c|}{ 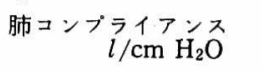 } & \multicolumn{3}{|l|}{0.055} & \\
\hline $\mathrm{PO}_{2}$ & $\mathrm{mmHg}$ & 68.7 & 69.7 & 75.7 & \\
\hline $\mathrm{PCO}_{2}$ & $\mathrm{mmHg}$ & 39.3 & 34.2 & 33.2 & \\
\hline $\mathrm{pH}$ & & 7.442 & 7.451 & 7.399 & \\
\hline
\end{tabular}

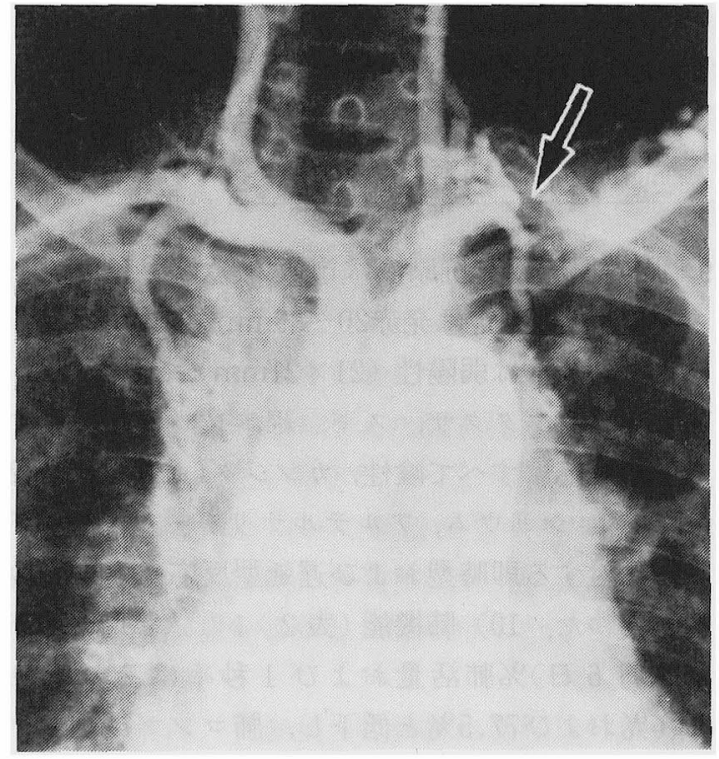

図 1．血管造影。左鎖骨下動脈の閉塞（矢印）

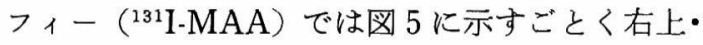
中肺野执よび左下肺野に血流障害を認めた。

筋電図所見； 上・下肢の近位筋执よび遠位筋 のいずれにも低振幅で多相性のNMUが観察され

る. 最大収縮時には十分な干渉が起こり, 安静時 にはfibrillation, positive sharp waveもみられる.

二頭筋生検所見；筋線維は大小不同，不揃い て組織球，リンパ球の浸潤を認める(図6).

経過(図 7 )：頝部が重く起㦿困難で, 下肢の 脱力のため歩行障害がみられた。発熱と胸部 $\mathrm{X}$ 線 写真における微細粒状影の出現に対し 8 月12日よ

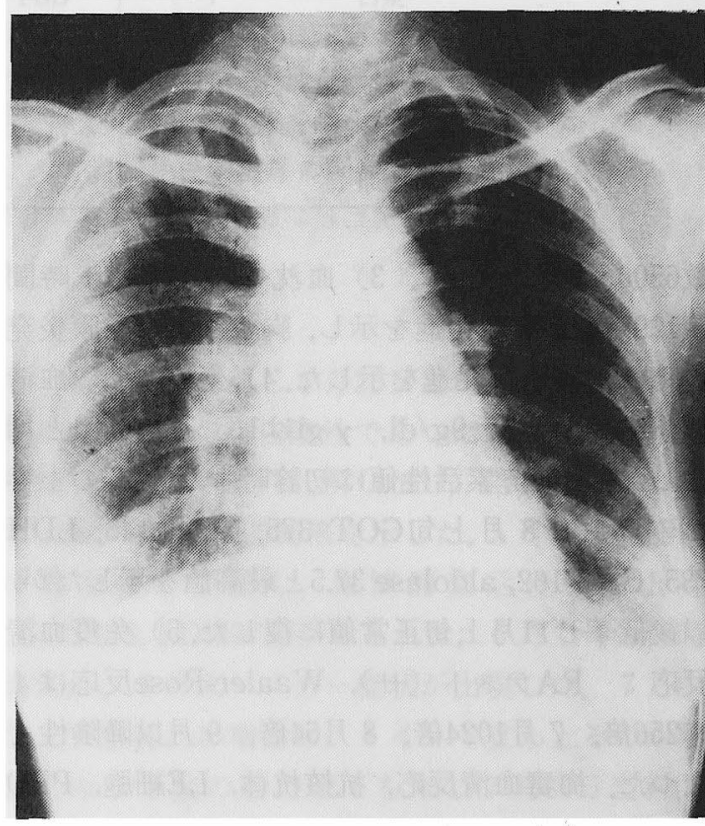

図 2．右側外側寄り扰よび両側下肺野にスリガラス様 陰影を認める（1976，8，5).

り cephalexinを投与した。 8 月下旬cephalexinに よると思われる著明な紅斑が上・下肢に出現した。 9 月 9 日肺野のスリガラス様陰影が拡大したので prednisoloneを投与した。下腿浮腫扣よび胸水貯 留を認めprednisolone 60mgに増量したが，筋症 状の改善なく歩行障害が続くので, prednisolone をさらに増量した、10月 7 日呼び掛けに応答しな くなり, 舌がもつれ発音が不明確となつた。精神 異常がみられ自分の名前がわからなくなり, “死ん 


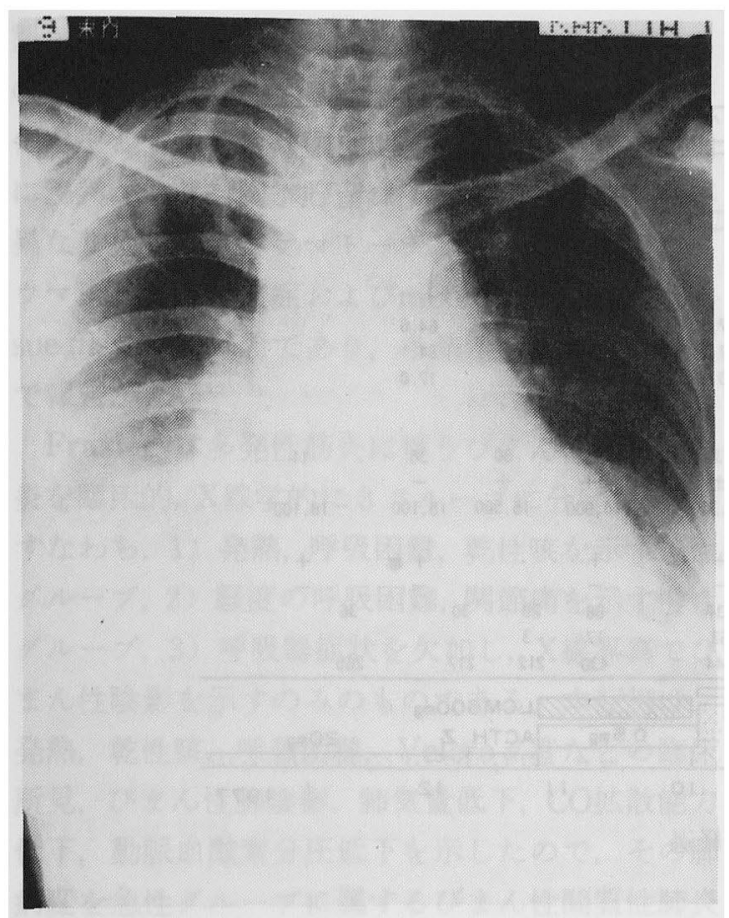

図 3、心陰影が拡大し，スリガラス様陰影は右中肺野 にもひろがつてきた，胸水貯留を認める（1976，9. 9).

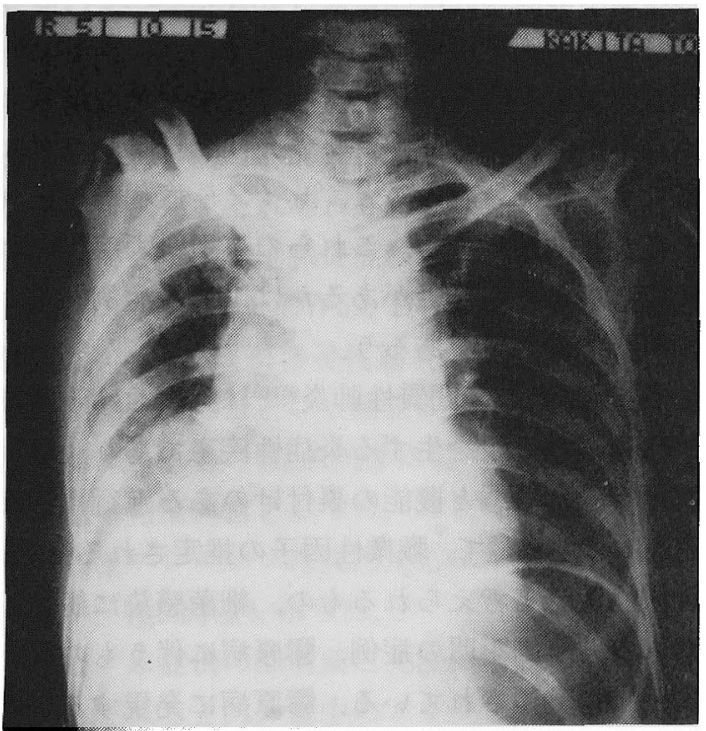

図 4. 右肺に胸水貯留を来した (1976.10，15，ポー タプル写真).

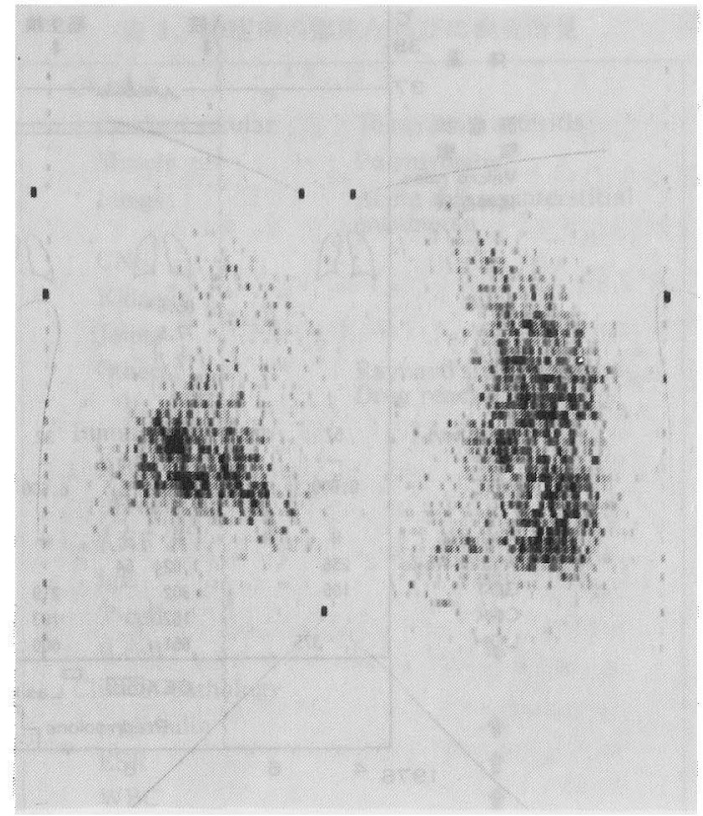

図 5。肺血流シンチグラム（1976，8，16）

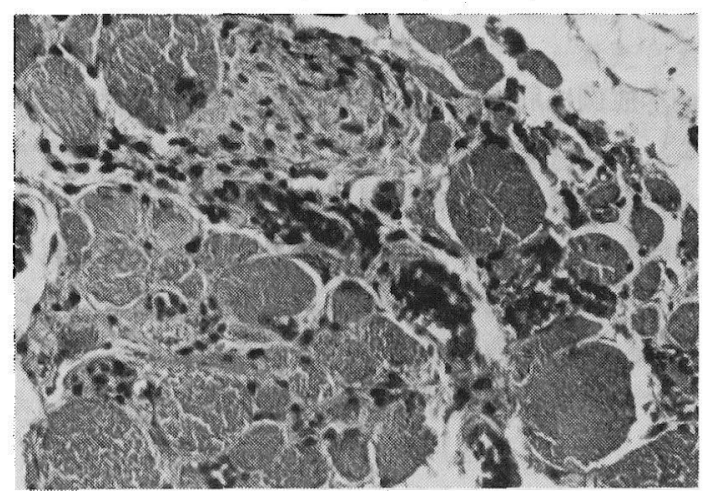

図 6.上腕二頭筋生検（HE染色）

でしまら゙などの独り言が続いた，10月13日精神 的にやや平静となつたが，経口摂取不能で体動困 難がみられた。精神症状の原因をステロイド薬に よるものと考えてACTH・Z筋注に変更した。この 頃より乾性咳嗽，呼吸困難が出現し，右胸部に声 音振とう, Velcroラ音を聴取した. 胸部X線写真で は心膜炎によると考兄られる心陰影の拡大がみら れた．10月20日胸腔穿刺を行なつたが，胸水は得 られなかつた。11月10日頃より咳嗽軽減し，呼吸 


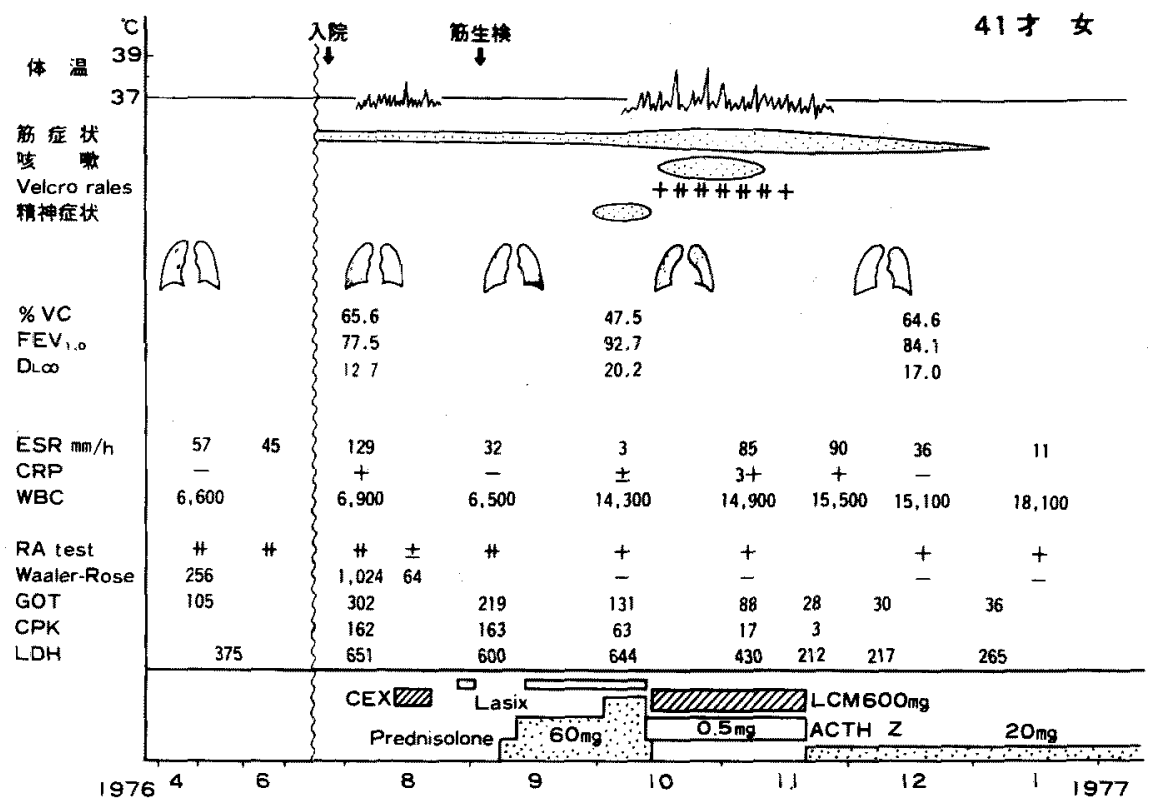

国 7。臨床経過

音正常となり，肺病変，筋症状ともに軽快した。

\section{考案}

本症例は筋力低下，労作時息切れが同時に出現 し，急性びん京性間質性肺炎を呈したが，ステロ イド療法により約 4 力月後肺病変，筋障害ともに 軽快した。大動脈炎症候群は 8 年前に指摘されて いて, 肺病変発症時は症痕期にあるものと考光ら れる，本症例の臨床病態恃大動脈资症候群に発症 乙た多発性筋炎に伴うび季几性間質性肺炎とい兄 上5.

さて，小出4)は大動脈炎症候群患者で膠原病の 既往歴のあるすの7.6\%(1,344例中102例)，経過 中に膠原病を合併した症例が $1.9 \%$ (26例) 之報告 している，大動脈炎症候群と多発性筋炎の合併は きわめて希でMiller ら5)（1962）と上田英雄 $5^{6)}$ （1966）の 2 例のみである，一方，多発性筋炎に伴 らびまん性間質性肺炎は近年報告例が増加し，欧 米で40数(列卓 3)，本邦で20数例 ${ }^{78)}$ 数える，乙か し，大動脈炎症候群，多発性筋炎，びま九性間質 珄肺炎の三つの疾患が同一個体に発現した症例は これあで報告がない。

大動脈炎症候群と多発性筋炎の合併例でMiller
ららの症例はレイノ一症状を示し，検查成續では LE細胞陽性，抗核抗体は陰性でリウマチ因子につ いては記戴がない.上田らのの症例は関節痛，レイ ノ一症状を示し，検查成續ではリウマチ反応陽性 を示した，本症例はレイノ一症状がみられたが， 関節痛は認めない.リウマチ因子陽性を示したが， 抗核抗体およびLE細胞は陰性であつた。これら3 例に共通した臨床的特徴として，患者が女性であ ること，大動脈炎症候群が多発性筋炎より先行し ていると推測されること，レイノ一症状がみられ ることがあげられる。これらの事項が両疾患の合 併にどのような意義があるかは，今後症例を重稀 て検討する必要があるう。

さて,びまん性間質性肺炎早10)は肺におけるる線維 性結合織の増生を生ずる炎症性疾患であり，臨床 病理学的に形態と機能の裏付けのある進行性肺疾 患をいう，そして，職業性因子の推定されるもの， 医原性疾患之考劣られるもの，細菌感染に続発し たもの，原因不明の症例，膠原病に伴うものなと 病因別に分類されている，膠原病に発現するびま 几性間質性肺炎1112) は基本的には共通した病变を 示すものと考えられているが，臨床経過では急性 
型と慢性型, 反応の強さでは出性反応の強いも の（例壳ば全身性エリテマトーデス）と線維性変 化を主とするもの（例光ば強皮症）があり疾患別 に差異がある。胸水貯留は疾患により出現頻度が 異なり全身性エリテマトーデス50〜 70\%，関節り ウマチ20\%，強皮症およびmixed connective tissue diseaseでは希であり，多発性筇炎ではこれま で報告がない12113)。

Frazier ${ }^{1}$ は多発性筋资に伴うびまん性間質性肺 炎を臨床的，X線学的に 3 グループに分けている. すなわち，1）発熱，呼吸困難，乾性咳を示す急性 グループ，2）軽度の呼吸困難，関節痛を示す慢性 グループ，3）呼吸器症状を欠如し，X線写真でび まん性陰影を示すのみのものである。本症例は， 発熱, 乾性咳, 呼吸困難, Velcroラ音などの臨床 所見，びを儿性肺陰影，肺気量低下，CO拡散能力 低下，動脈血酸素分王低下を示したので，その肺 病変を急性グループに属するびまん性間質性肺炎 と診断した。

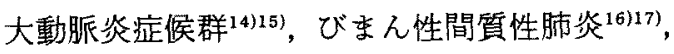
多発性筋炎 ${ }^{18)}$ の合併は二つの自己免疫疾患之膠原 病の合併であるが，これらの疾患が偶然に合併す る確率はきわめて低いと考えられ，その発症には 共通の免疫学的背景と体質的素因の存在が推察さ れる，3疾患におけるリウマチ因子の陽性率は大 動脈炎症候群で $4 \%$ (5) ないし $9 \%$, 多発性筋炎で $20 \%{ }^{18)}$, 間質性肺炎で $31.1 \%{ }^{16)}$,一方抗核抗体の陽 性率は各疾患でそれぞれ $6 \% ， 14 \% ， 36.5 \%$ と報 告されている。大動脈炎症候群の体質的素因につ いて磯久19) はHLA BW52, DW12に相関が深いと 報告している。亦た多発性筋炎では，B8，B14 と有 意の相関を認めたといら報告がある。しかし，本 症例ではこ机らのHLA抗原は認められなかつた。 その他の免疫異常としては，本例は抗ウイルス抗 体, 各種アレルゲンの皮内反応はすべて陰性であ つたが，IgE高值を示した。

さて，本症例の肺病変と免疫血清反応について 検討してみると，1）血中のリウマチ因子は肺発症 の初期に高值を示し，肺病変の進展に伴つて低下 した:これは肺組織への沈着によるる考えること
表 3、本症例の臨休ならびに検查所見

\begin{tabular}{|c|c|}
\hline \multicolumn{2}{|l|}{ Clinical } \\
\hline Cardio-vascular & Takayasu's arteritis \\
\hline Muscle & Polymyositis \\
\hline Lungs & $\begin{array}{l}\text { Acute diffuse interstitial } \\
\text { pneumonia }\end{array}$ \\
\hline CNS & + \\
\hline Kidney & - \\
\hline Joints & - \\
\hline Others & $\begin{array}{l}\text { Raynaud's phenomenon } \\
\text { Drug reaction }\end{array}$ \\
\hline \multicolumn{2}{|l|}{ Immunology } \\
\hline $\mathrm{RF}$ & + \\
\hline LE-cell & - \\
\hline ANF & - \\
\hline $\operatorname{IgE}$ & $\uparrow$ \\
\hline T-cell & $\Rightarrow$ \\
\hline B-cell & $\Rightarrow$ \\
\hline \multicolumn{2}{|l|}{ Clinical pathology } \\
\hline rglobulin & $\uparrow$ \\
\hline ESR & $\uparrow$ \\
\hline WBC & $\uparrow$ \\
\hline
\end{tabular}

も出来るので，リウマチ因子を肺発症の原因とみ なすTomasi ${ }^{20)}$ の説に一致する所見と考えられ る. 2) IgE高值を証明し，cephalexin投与により 薬疹を生じたが，これは過敏症あるいはアトピー 素因を示唆するもので, 本症例の肺発症の成因に I 型反応の関与を推測させる。本症例の胸膜预よ び心膜病変はびょん性肺陰影の増強に伴つて発現 し，ステロイド療法により軽快したので, 肺病変 と同じ成因に基づくものと考光られる。

MackayとBurnetは臨床的見地からの自己免疫 疾患の条件として六つの基準をあげている，本症 例の臨床像，免度異常，臨床検查成績を総括した ものが表 3 であるが，本例では(1) $1.5 \mathrm{~g} / \mathrm{dl}$ 以上の 高ガンマグロブリソ血症, (2) 自己抗体の検出, (3) ステロイド治療の有效性, (4) 自己免疫性症状・病 変の重複の四つの特徵を認めた。この結果から, 閉塞性血管病変, 筋障害, 肺病変の合併は免疫担 当組織の機能え進を主体とした病態であり, target tissueとして動脈, 横紋筋, 肺に対寸る障害の 目立つ病態と考兄るのが妥当であ万う，以上本症 例は自己免疫現象仙よつて惹起される疾患(いわ ゆる自己免疫疾患）に拈ける多彩な病態の発現に 
関して，示唆に富む貴重な症例と考光られる。

$$
\text { まとめ }
$$

大動脈炎症候群，多発性筋炎，びを儿性間質性 肺炎を合併した 1 例を報告した。筋障害と肺病変 は同時に発症し急性経過をとり，ステロイド療法 により軽快した。現在までにこのような症例は国 内外に例がなく，その病態の成因に関し考察を加 壳て報告した。

\section{文献}

1) Frazier $A R$ and Miller $R D$ : Interstitial pneumonitis in association with polymyositis and dermatomyositis. Chest 65: 403, 1974.

2) Schwarz MI et al: Interstitial lung disease in polymyositis and dermatomyositis. Medicine $55: 89,1976$.

3) Songcharoen $\mathrm{S}$, et al: Interstitial lung disease in polymyositis and dermatomyositis. J Rheum $7: 353,1980$

4）小出桂三：大動脈炎症候群。日本臨彇 $34: 1173$, 1976.

5) Miller $\mathrm{GAH}$, et al : Aortic arch syndrome and polymyositis with LE cells in peripheral blood. Brit Med J 1: $771: 1962$.

6）上田英雄，他：大動脈炎症候群を伴なつた多発性 筋炎の 1 剖検例。日内会誌 $55 ： 911 ， 1966$ 。

7) 三上理一郎，他：皮满筇炎の肺病变。日胸疾会誌 $37: 697,1978$

8）吉井昭夫，他：多発性筋炎の間質性肺病変に関す る臨床的並びに免疫学的研究。日内会誌 70 ： $1380,1981$.
9) Crystal RG, et al: Idiopathic pulmonary fibrosis. Ann Intern Med 85: 769, 1976.

10) Crystal RG, et al: Interstitial lung disease. Amer J Med 76: 542, 1981.

11）野沢幸男：膠原病における肺病变の病理組学的 研究.リウマチ $12: 159,1972$.

12) Hunninghake GW and Fauci AS: Pulmonary involvement in the collagen vascular diseases. Am Rev Respir Dis 119 : 471, 1979.

13) Harmon $C$, et al : Pulmonary involvement in mixed connective tissue disease (MCTD).

Arthritis Rheum 19: 801, 1976.

14）伊藤 臀：大動脈炎症候群。現代医療 $8: 1129$, 1976.

15) Lupi-Herrera $E$, et al: Takayasu's arteritis. Amer Heart J 93: 94, 1977.

16) Turner-Warwick $M$ and Haslam $P$ : Antibodies in some chronic fibrosing lung diseases. Clin Allergy $1: 83,1971$.

17) Turner-Warwick $M$ : A perspective view on widespread pulmonary fibrosis. Brit Med J 2 : 371, 1974.

18) Bohan A, et al: A computer assisted analysis of 153 patients with polymyositis and der matomyositis. Medicine $56: 255,1977$.

19）磯久一郎：高安病の体質的素因 HLA（histocompatibility antigens)systemからの検討。日 内会誌 $70 ： 992,1981$.

20) Tomasi TB Jr, et al : Possible relationship of rheumatoid factors and pulmonary disease. Amer J Med 33 : 243, 1962. 